Kinestetik : Jurnal Ilmiah Pendidikan Jasmani 5 (2) (2021)

Kinestetik : Jurnal Ilmiah Pendidikan Jasmani

https://ejournal.unib.ac.id/index.php/kinestetik/index

DOI : 10.33369/jk.v5i2.16376

\title{
THE RELATIONSHIP OF PHYSICAL ACTIVITIES AND STUDENT LEARNING OUTCOMES OF PHYSICAL EDUCATION
}

\author{
Tri Irianto ${ }^{1 *}$ Ramadhan Arifin ${ }^{2}$, Muhammad Firmansyah ${ }^{3}$ \\ ${ }^{123}$ Faculty of Teacher Training Education, Universitas Lambung Mangkurat, Indonesia
}

\section{Article Info \\ Article History : \\ Received : June 2021 \\ Revised : June 2021 \\ Accepted : June 2021 \\ Available online : June 2021}

Keywords:

Physical activity, learning outcomes.

\begin{abstract}
The purpose of this study was to determine the relationship between physical activity and learning outcomes of sports physical education and the health of students at SMA Negeri 1 Banjarbaru. The method used in this research is a survey method. The population in this study was taken from male and female students at the State Senior High School 1 Banjarbaru aged 16-19 years, the population in the XI grade of the State Senior High School 1 Banjarbaru as many as 231 students. In comparison, the research sample was 184 students with the cluster sampling technique.The results of the research on the physical activity of students of SMA Negeri 1 Banjarbaru found that the classification of "low" was 84 students with a percentage of $45.65 \%$. While the physical education learning outcomes of SMA Negeri 1 Banjarbaru students showed an average value of 82.11. The result of the calculation with the correlation shows 0.73 with the criteria of a strong/high relationship. Therefore, there is a relationship between physical activity and learning outcomes of PJOK students of SMAN 1 Banjarbaru. Physical education 85, high criteria as many as 21 people with an average score of 80.71 physical education. The criteria were as many as 71 people with an average score of 82.23 physical education. The low criteria were 84 people with an average score of 82.17 physical education and seven people with very low criteria with an average score of 85.57 physical education.
\end{abstract}

Corresponding address : trifkip@ulm.ac.id

Email : trifkip@ulm.ac.id
ISSN 2685-6514 (Online)

ISSN 2477-331X (Print) 


\section{INTRODUCTION}

The development of technology today is very fast. This development affects human aspects. Almost all the equipment needed by humans is fully automated and provides convenience. This is quite an impact on human health due to reduced activity in life. Healthy can be said to be physically, spiritually, and socially prosperous, not only free from disease, disability, or weakness. Health is everyone's hope, but it will never be obtained without adequate effort (TudorLocke, C., Williams, J. E., Reis, J. P., \& Pluto, 2002). Modern life habits in most people have eliminated all efforts to achieve physical fitness. We are accustomed to sitting on a soft chair while watching television, going everywhere by motorbike or car, sitting relaxed after a day of studying at school without any significant physical activity. If this goes on for a long time, eventually obesity is a source of various diseases. Get over us.

Physical fitness is a condition of the body that is able to carry out its daily tasks properly and efficiently, without significant fatigue, and the body still has spare energy, both to deal with sudden emergencies and to enjoy leisure time with active recreation (Hallal, P. C., Andersen, L. B., Bull, F. C., Guthold, R., Haskell, W., Ekelund, U., 2012). If we observe the physical fitness of a child who is good, then that child can perform various physical activities needed for development and growth. Physical fitness can also provide physical endurance to children, so they are not susceptible to disease.
Every student doing daily activities or activities at school has problems faced, such as feeling boredom, stress, and boredom. This usually arises due to a large number of activities or activities and tasks that are given daily at school. Many people choose their own way to get rid of boredom for activities, one of which is doing sports activities. Physical health will not be obtained by individuals who are sedentary. Everyone wants a healthy and fit body because it is the most important asset to carry out all activities in daily circumstances. One way to keep the body healthy and fit is by doing physical activity. Someone who is diligent in physical activity will create healthy physical and mental health so that it can make it easier to carry out all daily activities with insignificant levels of fatigue.

A good level of physical activity will greatly help children in following physical education lessons at school, and children will more easily concentrate on the material to be delivered by the teacher. SMA Negeri 1 Banjarbaru is located in a very strategic area. The condition of the surrounding environment also has many houses for residents who live in the vicinity. Most of the transportation used by students when going to and from school is taken by their parents using cars and motorbikes. The daily life of students has different activities, among others: some are participating in a football club, selfdefense training, swimming and usually these activities are carried out during outside school hours between the afternoons and holidays. In addition, the 
activities of students in everyday life still depend on the use of technology. From waking up to going to bed again, we have been facilitated by technology. The existence of technological advances has an impact on the physical fitness of students. In fact, students prefer lazing around at home watching television rather than having to do physical activity (sports), even though during their infancy, students have to do more physical activity than lazily watching television, just not doing anything. Not to mention that the learning results obtained later will certainly have an effect, where the physical activities carried out by students can be assessed from the learning outcomes. Students who have good physicality in following the physical education learning process will find it easier to adjust and accept and practice the material provided by the teacher effectively and efficiently.

Based on observations made by researchers in the field, the researcher argues that the level of physical activity of each student is different. However, to find out the level of physical activity of students, it is necessary to test the truth through a research survey, from the results of interviews with the Principal of SMA Negeri 1 Banjarbaru that so far, the school has never carried out tests and measurements of the level of physical activity of its students. Great hope this research can find out how the level of physical activity of students in school. After obtaining permission from the school, the writer tried to do research with the title of the relationship between the physical activity of students of SMA
Negeri 1 Banjarbaru on the learning outcomes of sports and health physical education.

\section{METHODS}

The method used in this research is a survey method. The survey method according to (Sugiyono, 2015) "the survey method is used to get data from a certain natural place, but the researcher performs treatment in data collection, for example distributing questionnaires, tests, interviews, and so on". To facilitate the implementation of research in the field, a research design was made as described in the variable relationship above (Thomas, J. R., Nelson, J. K., \& Silverman, 2005).

\section{Participants}

The population in this study was taken from male and female students at the State Senior High School 1 Banjarbaru aged 16-19 years; in this study specifically for class XI, which was allowed by the school, the population in the XI class of SMA Negeri 1 Banjarbaru was 231 students. While the research sample was 184 students

\section{Sampling Procedures}

The sampling technique used in this study was the cluster sampling technique considering that the sample was class XI student at the State Senior High School 1 Banjarbaru class, where all the students sampled had the desire to take part in the research. According to (Maksum, 2009) "Cluster sampling is a group or area of the population used as the research sample." 


\section{Materials and Apparatus}

The instruments used in this study were: 1) In measuring physical activity, researchers used the Physical Activity Questionnaire for Adolescents (PAQ-A) questionnaire by Kowalski, K. C., (Kowalski, K. C., Crocker, P. R., \& Donen, 2004) Instruments for collecting learning outcomes data with physical education learning outcomes documents (report card scores).

\section{Procedures}

The data needed in this study is the relationship between physical activity and learning outcomes. The data collection techniques will be carried out in several stages, namely: 1) Measuring physical activity using The Physical Activity Questionnaire for Adolescents (PAQ-A) questionnaire by (Kowalski, K. C., Crocker, P. R., \& Donen, 2004) The researcher also changes some physical activity items according to the circumstances of the sample studied. (Ardiyani, 2016) that changes or adjustments in the questionnaire were caused by differences in conditions or physical / sports activities. The change in activity is based on the results of sports observations that the researchers met at the State Senior High School 1 Banjarbaru. In addition, researchers made a special column if students did sports or activities that were not listed in the questionnaire. 2) Collecting data on learning outcomes with documents from physical education teachers at SMA Negeri 1 Banjarbaru.

\section{Design or Data Analysis}

The research data is in the form of quantitative data which will be calculated using the percentage descriptive technique. The percentage descriptive data analysis technique is intended to determine the status of the variable, namely to describe student learning outcomes through percentages According to (Arovah, 2012)

\section{RESULT}

The sample in this study were students who had an age range of 16-19 years. The variables studied in this study were physical activity data and physical education learning outcomes of students at SMA Negeri 1 Banjarbaru. After that, an in-depth analysis of the physical activities of each daily activity is carried out, by recording the data filling out the questionnaire that has been provided and distributed through the online google form as well as documentation in the form of students' final scores from physical education teachers at school.

Furthermore, the scores of each test result that have been carried out by both boys and girls are added and then matched with The Physical Activity Questionnaire for Adolescents (PAQ-A) by Kowalski, KC, Crocker, PR, \& Donen, $\mathrm{RM}$ in 2004, so that the results are obtained, namely Physical activity data. 
Students of SMA Negeri 1 Banjarbaru aged 16-19 years.

The results of the classification of the physical activity of students aged 1619 years at SMAN 1 Banjarbaru are presented in tables and histogram diagrams, which are as follows:

Table 1. Data Tabulation of Physical Activity of Students 16-19 Years Old

Data Tabulation

\begin{tabular}{l|ll}
\hline Criteria & Amount & $\%$ \\
\hline Very High & 10 & 0.54 \\
\hline High & 21 & 11.41 \\
\hline Moderate & 71 & 38.59 \\
\hline Low & 84 & 45.65 \\
\hline Very Low & 7 & 3.80 \\
\hline Total & 184 & $100 \%$ \\
\hline
\end{tabular}

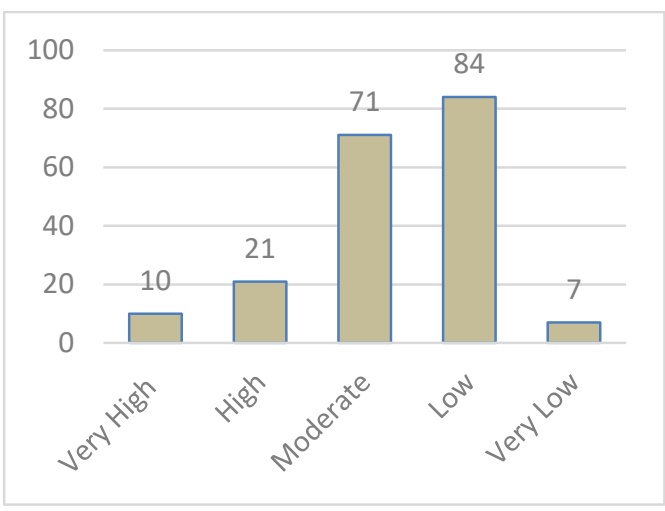

Figure 1. Prosentase physical activity

Table 2. Results of Recapitulation of Values

\begin{tabular}{c|cc}
\multicolumn{3}{c}{ and Percentage Results } \\
\hline Value & $\mathbf{f}$ & $\%$ \\
\hline $90-100$ & 2 & 1.09 \\
\hline $80-89$ & 125 & 67.93 \\
\hline $70-79$ & 57 & 30.98 \\
\hline $60-69$ & 0 & 0.00 \\
\hline $50-59$ & 0 & 0.00 \\
\hline & 184 & 100 \\
\hline
\end{tabular}

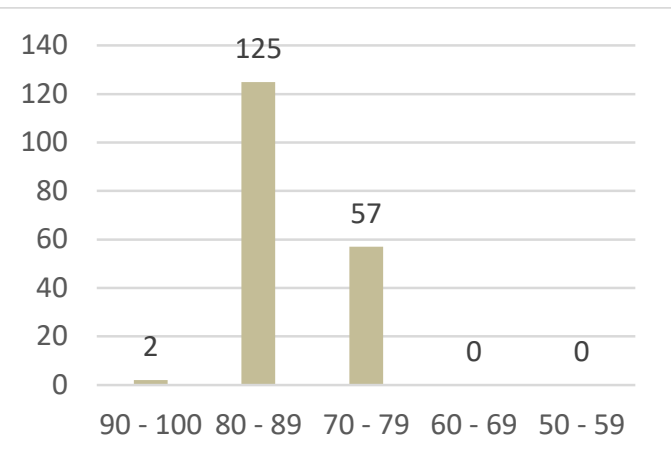

Figure 2. Student learning outcomes

From the results of the calculation of physical activity and the results of the average value of physical education of students of SMAN 1 Banjarbaru, it was found that there were five criteria, namely very high, only one person with an average score of 85 physical education and a percentage calculation of 0.53 . The high criteria are 21 people with an average score of 80.71 physical education and a percentage calculation of 11.23. As many as 71 people with an average score of 82.23 physical education and a percentage calculation of 37.97 . The low criteria were 84 people with an average score of 82.17 physical education and a percentage calculation of 44.92. and very low criteria as many as seven people with an average score of 85.57 physical education and a percentage calculation of 3.74 . 


\section{DISCUSSION}

This study aims to determine the daily activities and learning outcomes of students aged 16-19 years at SMA Negeri 1 Banjarbaru. The results of observations using google form with the instruments used with The Physical Activity Questionnaire for Adolescents (PAQ-A) by (Kowalski, K. C., Crocker, P. R., \& Donen, 2004). The percentage results show that the physical activity status of students aged 16- 19 years old for students of SMA Negeri 1 Banjarbaru with a very high classification with a total value of 5 with a total of 1 student, a percentage of $0.54 \%$. High classification with 21 students with a percentage of $11.41 \%$, moderate classification with 71 students with a percentage of $38.59 \%$, then in low classification with a total of 84 students with a percentage of $45.65 \%$, then very low classification with 7 students with a percentage of $3.80 \%$. The greatest observation results found in physical activity among students of SMA Negeri 1 Banjarbaru with the "low" classification were 84 students with a percentage of $45.65 \%$.

The learning result shows that the average score of students of SMA Negeri 1 Banjarbaru is 82.11 . Then the highest value is 94.00 , and the lowest value is 70.00. The learning result shows that the average score of students of SMA Negeri 1 Banjarbaru is 82.11 . This is included in a good score because the value is above 80 , if averaged over the entire population has met the graduation requirements in the physical education learning outcomes of SMA Negeri 1 Banjarbaru.
Based on the needs and data analysis that have been met, the results of the calculation of the Bivariate correlation or consisting of only two variables are connected by 0.73 . If we input into the interpretation criteria, the relationship is included in the strong and high relationship category. This indicates that there is a significant relationship between past physical activity and the learning outcomes of PJOK. Most likely, students before the pandemic that hit our region still did routine physical activities such as doing sports every day.

The result of the largest percentage found the number of physical activity in students of SMAN 1 Banjarbaru with the "low" classification was 84 students with a percentage of $45.65 \%$. Based on the results of the overall data analysis by collaborating between the average value of physical education and the results of physical activity of students at SMAN 1 Banjarbaru, it was found that only one person had very high physical activity criteria with a physical education value of only 85 . This indicates that someone is busy. Very different, and taking the time to do physical activity is different. Researchers also found that the results of the analysis of students with satisfactory physical education scores were 94, very good but still in the criteria of moderate and less physical activity. This is certainly different from the physical condition. The researchers concluded that these students have different skills from their other friends. Therefore, when physical education teachers take grades, these 
students show good performance until they get satisfactory grades.

During the Covid 19 pandemic, many students tend to be at home. Researchers believe that students' busyness is not only online learning but also making school assignments programmed by the teacher. Coupled with the existence of government regulations, there is a ban on leaving the house to avoid the spread of Covid 19. This daily activity shows a person's ability to deal with various kinds of activities he undertakes in a day. Especially when measured by a physical fitness test, the results are definitely not optimal. Therefore, in the midst of the Covid 19 pandemic, there is a ban on gathering large crowds. At the age of students in the 16-19 years range, this is the age where students reach the highest physical abilities, meaning that the physical form that can be built and built is directed anywhere if they are active in sports. Thus, in the midst of the current pandemic, students can only take their time to do the sports they like at home, both with the facilities and facilities they each have and do at home. The value of learning outcomes that are currently summarized is the value that fell in the even semester of the 2020/2021 school year, which was before the pandemic outbreak hit our area. Therefore, it cannot be denied that if there are no obstacles to re-measuring the physical fitness of students, researchers believe that there is a decrease in physical endurance and a decrease in the spirit of sports in the field.

\section{CONCLUSION}

Based on the results of the research and discussion, it can be concluded that the physical activity of the students of SMA Negeri 1 Banjarbaru was found to be classified as "low" as many as 84 students with a percentage of $45.65 \%$. While the physical education learning outcomes of SMA Negeri 1 Banjarbaru students showed an average value of 82.11. The result of the calculation with the correlation shows 0.73 with the criteria of a strong/high relationship. Therefore there is a link between physical activity and learning outcomes of PJOK students at SMAN 1 Banjarbaru.

From the results of the calculation of physical activity and the results of the average value of physical education of students of SMAN 1 Banjarbaru, it was found that there were five very high criteria, only one person with an average score of 85 physical education, and 21 people with an average score of physical education. 80.71. The criteria were as many as 71 people with an average score of 82.23 physical education. The low criteria were 84 people with an average score of 82.17 physical education and seven people with very low criteria. The results of this study indicate that during a pandemic, children must always exercise in order to keep the body healthy, fit and protected from various diseases.(Pane, 2015), (Prasetyo, 2013),(Sunardi, J., \& Kriswanto, 2020). 


\section{ACKNOWLEDGEMENT}

Thanks to Dean of the FKIP Lambung Mangkurat University who have supported the writing of this article.

\section{REFERENCES}

Ardiyani, D. (2016). Hubungan Antara Tingkat Aktivitas Jasmani Dengan Kesegaran Jasmani Siswa Putri Kelas VIII SMPN 3 Depok Yogyakarta Tahun Ajaran 2015/2016. Universitas Negeri Yogyakarta.

Arovah, N. I. (2012). Status Kegemukan, Pola Makan, Tingkat Aktivitas Fisik Dan Penyakit Degeneratif Dosen Dan Karyawan Universitas Negeri Yogyakarta. MEDIKORA, 1(5).

Hallal, P. C., Andersen, L. B., Bull, F. C., Guthold, R., Haskell, W., Ekelund, U., \& L. P. A. S. W. G. (2012). Global physical activity levels: surveillance progress, pitfalls, and prospects. The Lancet, 380, 247-257.

Kowalski, K. C., Crocker, P. R., \& Donen, R. M. (2004). The physical activity questionnaire for older children (PAQ-C) and adolescents (PAQ-A) manual. College of Kinesiology, University of Saskatchewan, 87(1), 1-38.

Maksum, A. (2009). Metodologi Penelitian Dalam Olahraga. FIK Unesa.

Pane, B. S. (2015). Peranan Olahraga Dalam Meningkatkan Kesehatan. Jurnal Pengabdian Kepada Masyarakat, 21(79), $1-4$.

Prasetyo, Y. (2013). Kesadaran masyarakat berolahraga untuk peningkatan kesehatan dan pembangunan nasional. MEDIKORA, 11(2).

Puspitasari, N. (2019). Faktor kondisi fisik terhadap resiko cedera olahraga pada permainan sepakbola. Jurnal Fisioterapi Dan Rehabilitasi, 3(1), 54-71.

Sugiyono. (2015). Metode Penelitian \& Pengembangan Research And Development. Bandung: Alfabeta.

Sugihartono, T., Yarmani, Y., \& Sutisyana, A. (2021). Pengukuran dan Analisis Kondisi Fisik Berbasis Labor Kelas Olahraga.
Jurnal Dharma Pendidikan dan Keolahragaan, 1(1), 37-46.

Sunardi, J., \& Kriswanto, E. S. (2020). Perilaku hidup bersih dan sehat mahasiswa pendidikan olahraga Universitas Negeri Yogyakarta saat pandemi Covid-19. Jurnal Pendidikan Jasmani Indonesia, 16(2), 156-167.

Thomas, J. R., Nelson, J. K., \& Silverman, S. J. (2005). Reseach Methods in Physical Activity. United States of America: Human Kinetics.

Tudor-Locke, C., Williams, J. E., Reis, J. P., \& Pluto, D. (2002). Utility of pedometers for assessing physical activity. Sports Medicine, 32(12), 795-808.

UTAMI, I., Ihsan, A., \& Yasriuddin, Y. (2019). Survei Kondisi Fisik Siswa yang Mengikuti Ektrakurikuler Bola Voli SMAN 1 Bantaeng (Doctoral dissertation, UNIVERSITAS NEGERI MAKASSAR).

Wiwoho, H. A., \& Junaidi, S. (2014). Profil Kondisi Fisik Siswa Ekstrakurikuler Bola Basket Putra Sma N 02 Ungaran Tahun 2012. Journal of Sport Science and Fitness, 3(1). 